\title{
Perancangan Sistem Informasi Akuntansi pada LAZIS Nurul Falah Surabaya
}

\author{
Nuril Firdaus ${ }^{1}$ \\ Email: nuril.17080694027@mhs.unesa.ac.id \\ Rohmawati Kusumaningtias ${ }^{2}$ \\ Email: rohmawatikusumaningtias@unesa.ac.id
}

\begin{abstract}
Effective and efficient zakat management requires the support of a good accounting information system. To improve the effectiveness and efficiency in ZIS management, an integrated information system is needed that helps in documenting ZIS collection and distribution activities and is easy to understand by system users. So that with the integrated accounting information system between divisions can improve the performance, accountability, and transparency of financial statements.

This research aims to design an accounting information system at LAZIS Nurul Falah. The Research method uses a case study approach. The data in the study were obtained through interviews with LAZIS Nurul Falah administrators who are directly related to research objects, observations, and documentation. Design an accounting information system using context diagrams, data flow diagrams, and flowcharts. The design of an integrated accounting information system using a client-server can improve the performance of administrators in managing data, accessing data, and speeding up the financial management process.
\end{abstract}

Keywords: Accounting Information System, Shari'ah Accounting, ZIS

\section{PENDAHULUAN}

Kemiskinan merupakan masalah utama dalam bidang ekonomi yang dihadapi oleh negara berkembang, salah satunya Indonesia. Salah satu penyebab munculnya masalah kemiskinan adalah kebutuhan primer manusia yang tidak terpenuhi secara menyeluruh dan rendahnya tingkat kesejahteraan ekonomi. Rendahnya tingkat kesejahteraan menggambarkan rendahnya kondisi produktivitas yang mengindikasikan bahwa pemanfaatan sumber daya kurang optimal (Robimadin dan Cahyono 2020).

\footnotetext{
${ }^{1}$ Corresponding author: Fakultas Ekonomi, Universitas Negeri Surabaya, Jalan Ketintang No. 2, Surabaya, Jawa Timur, 60231

${ }^{2}$ Fakultas Ekonomi, Universitas Negeri Surabaya, Jalan Ketintang No. 2, Surabaya, Jawa Timur, 60231
} 
Dilansir dari Tirto.Id, per Maret 2020 tercatat angka kemiskinan mengalami kenaikan menjadi 26,42 juta orang. Angka kemiskinan yang naik secara otomatis berpengaruh pada presentase penduduk miskin, sehingga persentase penduduk miskin per Maret 2020 mengalami kenaikan sebesar 9,78\%. Salah satu kota yang menghadapi masalah kemiskinan adalah Kota Surabaya. Berdasarkan data dari Badan Pusat Statistik Kota Surabaya (2020), dalam 4 tahun terakhir angka kemiskinan di Kota Surabaya mengalami penurunan. Berikut data presentase kemiskinan Kota Surabaya tahun 2016-2019

Tabel 1.1 Jumlah Penduduk Miskin Kota Surabaya (Disajikan dalam Ribuan
\begin{tabular}{|l|llll|}
\hline Orang) \\
\hline Tahun & 2016 & 2017 & 2018 & 2019 \\
\hline Persentase & 5,63 & 5,39 & 4,88 & 4,51 \\
\hline Jumlah & 161,01 & 154,71 & 140,81 & 130,55 \\
\hline
\end{tabular}

Sumber: Badan Pusat Statistik Kota Surabaya (2020)

Tabel 1.1 menunjukkan bahwa dalam kurun waktu 4 tahun terakhir, presentase jumlah penduduk miskin Kota Surabaya mengalami penurunan kurang dari $1 \%$, sehingga penurunan ini dinilai tidak signifikan. Menurunnya angka kemiskinan yang tidak signifikan ini menunjukkan lambatnya upaya pengentasan kemiskinan, karena sumber anggaran yang diandalkan oleh negara hanya berasal dari anggaran pemerintah (Robimadin dan Cahyono 2020). Untuk mengatasi keterlambatan dalam pengentasan kemiskinan, pemerintah memerlukan model alternatif agar pengentasan kemiskinan dapat berjalan lebih cepat (Robimadin dan Cahyono 2020).

Zakat dipandang sebagai salah satu upaya yang dapat dimanfaatkan dalam mengatasi masalah kemiskinan dan menghilangkan kesenjangan sosial di masyarakat. Menurut Firdaus (2015) melalui program ZIS, Negara Indonesia berpotensi untuk meningkatkan kualitas dalam bidang sosial karena penduduk Indonesia mayoritas pemeluk agama Islam yang wajib membayar zakat. Zakat dipandang sebagai sumber pendanaan potensial yang dapat dimanfaatkan dalam peningkatan kesejahteraan masyarakat, sehingga zakat berperan dalam mengatasi masalah ekonomi (Lathifah 2019). Agar zakat berpengaruh signifikan dalam upaya mengatasi masalah perekonomian masyarakat, maka potensi zakat harus dioptimalkan.

Mayoritas penduduk Indonesia merupakan pemeluk agama Islam, sehingga potensi zakat di Indonesia pun tinggi. Secara demografik, potensi zakat di Indonesia memiliki peluang untuk dikembangkan menjadi instrumen pemerataan pendapatan melalui organisasi pengelola ZIS (Kristin \& Umah, 2011). Berdasarkan hasil perhitungan komponen Indikator Pemetaan Potensi Zakat (IPPZ) per tahun 2019, jumlah potensi zakat sebagai berikut.

Tabel 1.2 menunjukkan bahwa total potensi zakat di Indonesia berdasarkan perhitungan IPPZ mencapai Rp 327,6 triliun. Dari 5 komponen objek zakat, potensi zakat terbesar pada zakat perusahaan dengan jumlah mencapai Rp 144,5 triliun dan zakat penghasilan dan jasa dengan jumlah mencapai Rp 139,07 triliun. Jumlah tersebut menunjukkan jumlah potensi zakat di Indonesia yang bisa dimanfaatkan dengan maksimal dalam program penghimpunan dana ZIS oleh Lembaga Amil Zakat (Puskas BAZNAS 2021). 
Tabel 1.2 Potensi Zakat di Indonesia

\begin{tabular}{|c|c|}
\hline Objek Zakat & $\begin{array}{c}\text { Potensi Zakat } \\
\text { (Triliun Rupiah) }\end{array}$ \\
\hline Zakat Pertanian & 19,79 \\
\hline Zakat Peternakan & 9,51 \\
\hline Zakat Uang & 58,76 \\
\hline Zakat Perusahaan & 144,5 \\
\hline Zakat Penghasilan dan Jasa & 139,07 \\
\hline Total potensi zakat & $\mathbf{3 2 7 , 6}$ \\
\hline
\end{tabular}

Sumber : Puskas BAZNAS 2021

Untuk memaksimalkan potensi zakat, diperlukan organisasi yang bertugas untuk mengumpulkan, mengelola, dan mendistribusikan zakat. Berdasarkan UndangUndang No. 23 tahun 2011 tentang pengelolaan zakat, terdapat 2 organisasi bertugas dalam pengelolaan zakat, yaitu Badan Amil Zakat (BAZ) yang dibentuk oleh pemerintah dan Lembaga Amil Zakat (LAZ) yang dibentuk oleh masyarakat (Rahman, 2015). LAZ memiliki tugas untuk membantu BAZ dalam mengumpulkan dan mendistribusikan ZIS.

Efektivitas dan efisiensi pengelolaan zakat perlu didukung oleh sistem informasi akuntansi yang baik. Sistem yang terintegrasi dengan teknologi informasi memudahkan dalam mengelola zakat, meningkatkan efisiensi dalam pengumpulan dana oleh Lembaga Amil Zakat, memudahkan dalam penyimpanan data, dan memperkuat database yang diperlukan oleh pengelola zakat (Dulkiah 2017). Menurut Firdaus (2015), sistem informasi sangat penting bagi badan usaha dalam membantu mendokumentasikan aktivitas sehari-hari seperti: pencatatan transaksi dan dapat membantu dalam pengambilan keputusan. Efektivitas sistem informasi akuntansi dalam pengelolaan zakat memuat kemudahan penggunaan sistem yang jelas dan mudah dipahami, sehingga dapat membantu pekerjaan pengguna. Efektivitas sistem informasi memengaruhi efektivitas informasi akuntansi. Efektivitas informasi akuntansi tercapai apabila efektivitas sistem informasi akuntansi memenuhi syarat (Komala 2017). Dalam penelitian Lisa Ernawatiningsih dan Kepramareni (2019) disebutkan bahwa sistem informasi akuntansi dikatakan efektif apabila menghasilkan informasi yang berkualitas, hal ini dikarenakan suatu informasi dapat meningkatkan kinerja suatu organisasi. Rosa dan Purfini (2019) menyatakan sistem informasi akuntansi mempengaruhi kualitas informasi akuntansi, karena informasi akuntansi menjadi tidak berkualitas apabila tanpa didukung sistem informasi akuntansi yang berkualitas pula. Lembaga Amil Zakat dalam mengelola dana zakat sangat memerlukan sistem informasi akuntansi yang baik dalam pencatatan dan pelaporan keuangan, sehingga laporan keuangan yang dihasilkan oleh Lembaga Amil Zakat adalah valid dan terpercaya (Lathifah 2019). Sehingga memerlukan sistem informasi akuntansi yang mendukung dan tepat dalam pengembangan sistem pelaporan keuangan zakat (Lathifah 2019).

LAZIS Nurul Falah merupakan Lembaga yang mendistribusikan Zakat, Infaq, dan Shadaqah (ZIS) dalam bidang pendidikan Al-Quran. Penelitian ini mengambil objek LAZIS Nurul Falah Surabaya. Berdasarkan hasil wawancara disimpulkan bahwa terdapat 3 masalah dalam penerapan sistem informasi akuntansi pada LAZIS Nurul Falah. Pertama, penerapan sistem informasi akuntansi pada LAZIS Nurul Falah belum menggambarkan satu siklus yang terintegrasi. Sistem informasi yang tidak 
terintegrasi dapat menghambat proses pencatatan dan pelaporan keuangan. Sedangkan sistem informasi berperan penting dalam pengelolaan Lembaga dan penerapan sistem pengendalian internal (Soudani 2012). Kedua, pengguna aplikasi pencatatan keuangan (bagian admin dan keuangan) belum memahami pentingnya fungsi sistem informasi akuntansi dan peran sistem pengendalian internal pada LAZIS Nurul Falah. Ketiga, laporan keuangan yang dihasilkan belum sepenuhnya sesuai dengan PSAK No. 109 yang mengatur mengenai pengakuan, penyajian, dan pengungkapan transaksi zakat, infaq, dan shadaqah. Ketiga permasalahan ini menyebabkan kurangnya transparansi pengelolaan zakat pada LAZIS Nurul Falah.

Berdasarkan permasalahan diatas, peneliti tertarik untuk melalukan penelitian pada LAZIS Nurul Falah dengan melakukan perbaikan dan pengembangan terhadap sistem informasi akuntansi yang telah diterapkan pada LAZIS Nurul Falah untuk memudahkan dan mempercepat proses penyusunan laporan keuangan sesuai PSAK No. 109, serta memperkuat sistem pengendalian internal pada LAZIS Nurul Falah guna meningkatkan transparansi dalam mengelola ZIS.

Penelitian ini merujuk pada penelitian sebelumnya yang dilakukan oleh Lathifah (2019) yang melakukan perancangan pada organisasi pengelola zakat dengan sistem AZIS. Firdaus (2015) melakukan perancangan sistem informasi akuntansi pada Masjid dengan menggunakan DFD, flowchart sistem, diagram konteks, dan ERP. Abral, Anwar, dan Harianto (2016) melakukan perancangan sistem informasi akuntansi pada LAZ dengan menggunakan DFD dan ERD dalam mendesain sistem. Perbedaan penelitian sebelumnya dan penelitian ini terletak pada desain DFD dan flowchart yang didesain sesuai dengan kebutuhan Lembaga.

\section{KAJIAN LITERATUR DAN PENGEMBANGAN HIPOTESIS 2.1 Zakat, Infaq, dan Shadaqah}

Menurut Bahasa, zakat dapat diartikan sebagai al-barakah (keberkahan), alnama (pertumbuhan dan perkembangan), dan at-taharatu (kesucian) (Bashori 2017). Sedangkan menurut istilah, zakat berarti kewajiban untuk menyerahkan harta dengan jumlah tertentu yang dibayarkan oleh umat islam, kemudian diserahkan kepada orang yang memilik hak untuk menerima (Wantoro 2019). Zakat menurut PSAK No. 109 merupakan harta yang wajib dikeluarkan oleh Mustahik untuk diberikan kepada Muzakki sesuai dengan ketentuan Syariah (Ikatan Akuntan Indonesia, 2008). Sehingga disimpulkan bahwa zakat adalah harta dengan jumlah tertentu yang diberikan kepada orang yang berhak menerima dan menjadi suatu keberkahan bagi penerima zakat. Adanya zakat diharapkan menjadi salah satu alternatif dalam peningkatan kesejahteraan dan meningkatkan perekonomian, karena zakat menyebabkan proses distribusi harta dari masyarakat kaya ke masyarakat miskin (Purwanti 2020). Adapun golongan yang berhak atas zakat telah tercantum dalam AlQur'an Surat At-Taubah ayat 60, yaitu terbagi menjadi 8 asnaf, diantaranya: orang fakir, orang miskin, mualaf, amil, hamba sahaya, ibnu sabil, fisabilillah, dan gharim (Bashori 2017).

Menurut PSAK No 109, Infaq/sedekah merupakan harta yang diberikan oleh pemiliknya secara sukarela, baik diperuntukkannya dibatasi maupun tidak terbatas (Ikatan Akuntan Indonesia 2008). Infaq adalah harta yang dikeluarkan oleh individu tanpa adanya ketentuan jumlah dan waktu pemberian secara sukarela. Besarnya jumlah infaq bergantung kepada kondisi keuangan dan keikhlasan pemberi (Wantoro 2019). Dalam penyaluran infaq, tidak ada ketentuan penerimanya. Namun, dalam 
anjuran agama Islam infaq dikeluarkan kepada orang-orang fakir (Bashori 2017). Sedangkan shadaqah adalah pemberian berupa materi maupun non-materi kepada fakir-miskin atau orang yang membutuhkan secara ikhlas tanpa adanya unsur paksaan (Kristin dan Umah 2011). Hukum memberi shadaqah adalah sunnah, sehingga tidak ada batasan jumlah pemberian dan ketentuan waktu.

\subsection{Lembaga Amil Zakat}

Rahman (2015), Lembaga Amil Zakat merupakan Lembaga yang dibentuk oleh masyarakat atas izin dari Menteri atau Pejabat yang berkepentingan untuk melaksanakan kegiatan penghimpunan, pendistribusian, dan pendayagunaan ZIS. LAZ wajib melaporkan laporan pengelolaan ZIS hasil audit kepada BAZNAS pada akhir tahun (Rahman 2015). LAZ berperan dalam upaya mengoptimalkan perolehan dana zakat, infaq, dan shadaqah (ZIS) dengan menggunakan strategi penghimpunan dana yang dilakukan secara maksimal (Kusmanto 2014).

\subsection{Sistem Informasi Akuntansi}

Sistem informasi adalah kumpulan bagian-bagian sistem yang terhubung antara satu dengan yang lain dan bekerja sama untuk memproses data menjadi suatu informasi (Susanto 2017). Menurut Kieso, Weygandt, dan Warfield (2011) sistem informasi adalah suatu sistem yang mengumpulkan dan memproses data transaksi harian menjadi informasi yang disebarkan kepada pihak yang memiliki kepentingan dalam suatu organisasi. Sistem informasi berisi serangkaian kegiatan yang terorganisasi dalam bentuk prosedur-prosedur, apabila prosedur dilakukan dapat menghasilkan informasi yang menjadi dasar dalam pengambilan keputusan dan pengendalian internal organisasi (Abral, Anwar, dan Harianto 2016). Sehingga dapat disimpulkan bahwa sistem informasi adalah kumpulan beberapa bagian sistem terintegrasi dalam proses perubahan data menjadi informasi yang dijadikan dasar dalam pengambilan keputusan dan sebagai pengendali organisasi.

Bodnar (2013), sistem informasi akuntansi adalah perancangan sistem terkomputerisasi untuk memproses data akuntansi menjadi informasi. Borhan dan Nafees (2018) Sistem informasi akuntansi merupakan sistem berbasis komputer yang mengumpulkan data, memproses dan menganalisis data keuangan hingga menghasilkan informasi keuangan. Informasi dari output pemrosesan data tersebut dapat menjadi dasar pengambilan keputusan organisasi. Noerlina, Johan, dan Yoswara (2011) Sistem informasi akuntansi membantu mengumpulkan informasi dengan mengubah data mentah menjadi data keuangan untuk tujuan pelaporan yang kemudian digunakan untuk membuat keputusan. Berikut proses sistem informasi dalam mengubah suatu data menjadi informasi.

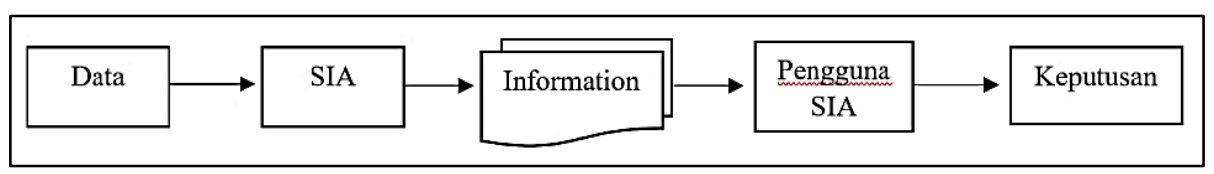

Sumber: Romney, Marshall B., dan Paul John Steinbart. 2017. Accounting Information Systems Fourteenth Edition. United Stated of America: Pearson. hal.11

Gambar 2.1. Proses Perubahan Data menjadi Informasi 
Penggunaan sistem informasi akuntansi secara optimal pada suatu Lembaga dapat memberikan manfaat bagi organisasi, yaitu memudahkan organisasi dalam beradaptasi dengan lingkungan yang terus mengalami perubahan, sistem pengendalian internal lebih baik, dan meningkatkan hubungan eksternal organisasi (Ganyam dan Ivungu 2019).

\subsection{Pengembangan Sistem Informasi Akuntansi}

Pengembangan sistem adalah proses modifikasi atau mengubah sistem informasi, baik sebagian atau keseluruhan (Lathifah 2019). Dalam pengembangan sistem terdapat siklus hidup pengembangan sistem (The Systems Development Life Cycle) yang terdiri dari perencanaan dan analisis, desain, dan implementasi. Setiap bagian dalam siklus tersebut saling berkaitan, apabila ada bagian dari siklus yang diabaikan maka akan berakibat serius dalam pengerjaan proyek tersebut (Bodnar dan Hopwood 2013).

Lathifah (2019) Tahap pengembangan sistem terdapat 3 tahap utama, yaitu (1) Perencanaan dan analisis sistem; (2) Desain Sistem; dan (3) Implementasi sistem.

\section{Perencanaan dan Analisis Sistem}

Perencanaan sistem dalam pengembangan melibatkan proses identifikasi sub sistem yang memerlukan perhatian secara khusus dalam sistem informasi. Perencanaan sistem bertujuan untuk mengidentifikasi masalah yang perlu ditangani dengan segera atau masalah yang mungkin akan muncul mendatang (Bodnar dan Hopwood 2013). Analisis sistem merupakan tahap dari pengembangan sistem setelah perencanaan sistem dilakukan. Analisis sistem fokus pada identifikasi kebutuhan informasi dan persyaratan sistem untuk dilakukannya perbaikan terhadap sistem yang saat ini digunakan organisasi (Lathifah 2019). Persyaratan sistem akan diterjemahkan dalam aplikasi khusus dalam tahap desain dan implementasi sistem (Bodnar dan Hopwood 2013).

Menurut Romney dan Steinbart (2017) tahapan dalam analisis sitem terbagi dalam 2 tahap, yaitu: (1) tahap survei sistem (systems survey), dan (2) tahap studi kelayakan (feasibility study). Tujuan dari tahap survey pendahuluan, sebagai berikut

1. Memahami operasi, kebijakan, prosedur, dan informasi organisasi yang ada

2. Menjalin relasi yang baik dengan pengguna sistem

3. Mengumpulkan informasi yang berguna dalam pengembangan sistem

4. Identifikasi dan memahami masalah yang dihadapi

Tujuan dari tahap studi kelayakan adalah untuk mencari sistem baru atau memperbaiki sistem yang sedang berjalan, dan mengidentifikasi hal yang diperlukan untuk memperbaiki sistem lama atau penerapan sistem baru (Lathifah 2019).

2. Desain Sistem

Desain Sistem merupakan tahap lanjutan dari analisis sistem untuk merancang secara rinci solusi yang dipilih (Lathifah 2019). Desain sistem adalah proses perancangan model baru atau memodifikasi sistem yang ada (Bodnar dan Hopwood 2013). Desain sistem diklasifikasikan menjadi 2 kelompok, yaitu (1) desain konseptual; dan (2) desain fisik. Menurut Lathifah (2019) tahap perancang koseptual merancang berbagai komponen sistem secara manual atau secara konsep. Hal-hal yang dirancang dalam tahap ini adalah struktur organisasi, prosedur, dokumen dan laporan, basis data, diagram, dan tampilan layar yang akan diterjemahkan dalam program komputer. Romney dan Steinbart (2017) dalam desain konseptual terdapat 3 
tahap, terdiri (a) Mengevaluasi Desain Alternatif, (b) Menyiapkan Spesifikasi Desain, dan (c) Mengembangkan Laporan Desain.

Perancangan fisik merupakan tahap lanjutan dari tahap sebelumnya. Dalam tahap perancangan fisik, perancang sistem memulai untuk mewujudkan rancangan yang telah dibuat dalam tahap perancangan konseptual dan diterjemahkan dalam spesifikasi rinci yang digunakan untuk membuat kode (Lathifah 2019).

3. Implementasi Sistem

Implementasi sistem adalah proses menginstal hardware dan software yang menjalankan sistem informasi akuntansi (Romney dan Steinbart 2017). Proses implementasi sistem terdiri dari 7 tahap. Tahapan implementasi sistem digambarkan pada Gambar 2.2 sebagai berikut

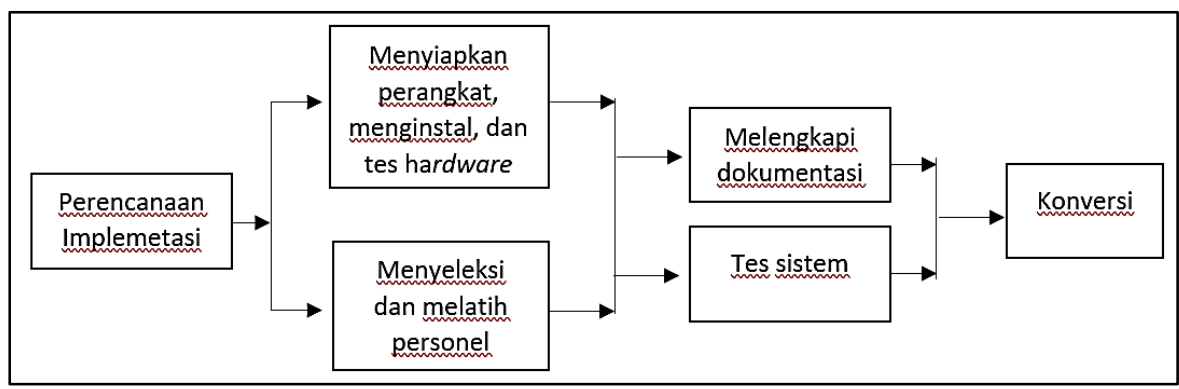

Sumber: Romney, Marshall B., dan Paul John Steinbart. 2017. Accounting Information Systems Fourteenth Edition. United Stated of America: Pearson. hal.691 Gambar 2.2. Proses Implementasi Sistem

\subsection{Akuntansi Zakat dan Infak/Shadaqah}

Menurut American Accounting Association, akuntansi diartikan sebagai proses identifikasi, pencatatan, pengklasifikasian dan komunikasi kegiatan ekonomi entitas yang diinterpretasikan dalam bentuk laporan keuangan yang digunakan untuk membuat keputusan (Habib 2016). Sedangkan definisi akuntansi berdasarkan sudut pandang Syariah adalah proses akuntansi yang memberikan informasi yang tepat kepada stakeholders organisasi yang memastikan bahwa organisasi terus beroperasi dengan menerapkan prinsip Syariah Islam dan mewujudkan sosial ekonomi (Nurhayati 2013). Sehingga dapat disimpulkan bahwa dari 2 definisi akuntansi tersebut terdapat perbedaan. Penyajian informasi dalam akuntansi Syariah memiliki cakupan yang lebih luas, bukan hanya mengenai keuangan organisasi melainkan aktivitas organisasi yang dijalankan berdasarkan prinsip Syariah dan bergerak dalam bidang sosial dan ekonomi. Sedangkan akuntansi secara konvensional, informasi yang disajikan mengenai keuangan entitas dan laba yang diperoleh entitas.

Habib (2016) Tujuan akuntansi zakat adalah pertama, untuk memberikan laporan kepada Muzakki yang telah mempercayakan pengelolaan dana ZIS kepada lembaga. Tujuan ini berkaitan dengan pengendalian internal organisasi. Kedua, sebagai pertanggungjawaban organisasi dalam mengelola ZIS. Tujuan ini berkaitan dengan akuntabilitas, Lembaga menerbitkan laporan kepada publik atas aktivitas organisasi dan pendayagunaan dana umat (Habib 2016). Selain itu, laporan keuangan memerlukan transparansi untuk memastikan pengelolaan dana ZIS dilakukan dengan baik dan untuk mencegah adanya tindakan menyimpang (Asmarani dan Kusumaningtias 2019). 
IAI mengeluarkan Pernyataan Standar Akuntansi Keuangan (PSAK) No 109 tentang Akuntansi Zakat dan Infak/Shadaqah yang mengatur pengakuan, pengukuran, penyajian, dan pengungkapan transaksi zakat dan infak/shadaqah (Ikatan Akuntan Indonesia 2008). Ruang lingkup akuntansi zakat hanya mencakup amil sebagai penerima dan penyalur zakat dan infak/shadaqah. Penerapan PSAK No 109 ini bersifat wajib bagi organisasi pengelola zakat, baik organisasi yang telah memiliki izin atau organisasi yang belum memiliki izin. Sebagai bentuk pertanggungjawaban amil kepada Muzakki, Amil harus menyusun laporan keuangan yang informatif dan kredibel.

\subsection{Sistem Pengendalian Internal}

Menurut COSO (2012) pengendalian internal adalah suatu proses yang didalamnya terdapat pengaruh Dewan Direksi, Manajemen, dan anggota entitas yang dirancang untuk memberikan jaminan yang wajar mengenai tercapainya tujuan terkait operasional, pelaporan, dan kepatuhan. Sistem pengendalian internal adalah proses yang ditetapkan oleh manajemen dan dijalankan oleh pengurus organisasi untuk memberikan keyakinan atas capaian tujuan organisasi, efektivitas dan efisiensi kegiatan organisasi dan keandalan laporan keuangan (Olifia, Irsutami, dan Sinarti 2018). Sistem pengendalian internal meliputi prosedur yang harus dijalankan oleh seluruh anggota pengurus suatu organisasi untuk mencapai tujuan pengendalian (Romney dan Steinbart 2017). Tuanakotta (2019) Tujuan pengendalian internal terdapat 3 kategori, yaitu (1) Tujuan operasional yang berkaitan dengan efektivitas dan efisiensi kegiatan operasional organisasi, (2) Tujuan pelaporan berkaitan dengan pelaporan keuangan baik internal maupun eksternal, (3) Tujuan ketaatan berkaitan dengan kepatuhan organisasi terhadap kebijakan, peraturan, atau ketentuan undangundang yang berlaku.

Menurut COSO (2012), terdapat 5 komponen pengendalian internal, yaitu lingkungan pengendalian, penilaian risiko, aktivitas pengendalian, informasi dan komunikasi, dan pemantauan. Lingkungan pengendalian berkaitan dengan kondisi lingkungan kerja organisasi, sehingga diperlukan peran pimpinan untuk menciptakan kebijakan terkait lingkungan kerja organisasi. Penilaian risiko berkaitan dengan kemungkinan risiko yang akan dihadapi oleh organisasi. Aktivitas pengendalian berkaitan dengan tindakan preventif untuk mencegah kemungkinan risiko yang terjadi. Informasi dan komunikasi berkaitan dengan kualitas informasi yang diberikan dan cara komunikasi baik dengan pihak internal atau pihak eksternal organisasi. Pemantauan berkaitan dengan proses pengawasan terhadap kebijakan yang telah ditetapkan berjalan dengan baik.

\section{METODE PENELITIAN}

Metode penelitian kualitatif ini menggunakan pendekatan studi kasus. Penelitian studi kasus merupakan penelitian yang memperhatikan seluruh aspek penting dari kasus yang diteliti. Jenis penelitian kualitatif adalah penelitian berdasarkan fenomena yang dialami oleh subjek penelitian dengan tujuan untuk memahami dan menafsirkan fenomena yang terjadi secara nyata pada suatu tempat (Hidayah dan Nawirah 2020). Menurut Yusuf (2017) Penelitian studi kasus merupakan penelitian yang proses pengumpulan data dan informasi dilakukan secara mendalam dan detail sehingga dapat menggambarkan obyek penelitian atau suatu situasi. 
Data yang digunakan dalam penelitian adalah data primer dan data sekunder. Data primer diperoleh dari wawancara dengan Pimpinan dan Manager Keuangan LAZIS Nurul Falah dan observasi. Data sekunder diperoleh dari dokumentasi dan arsip LAZIS Nurul Falah. Data sekunder yang dibutuhkan dalam penelitian terdiri dari bagan struktur organisasi, job description, bukti pembayaran ZIS, formulir pendaftaran Muzakki dan laporan keuangan. Proses analisis data yang diperoleh dilakukan dengan langkah-langkah berikut: 1) Mengumpulkan data primer dan data sekunder yang telah diperoleh, 2) Melakukan reduksi data dengan merangkum hasil wawancara menjadi bentuk teks yang mudah dipahami, 3) Melakukan penyajian data dalam bentuk teks naratif, flowchart, dan tabel, dan 4) Menarik kesimpulan berdasarkan hasil proses reduksi data.

\section{HASIL PENELITIAN DAN PEMBAHASAN}

\subsection{Analisis Sistem dan Rekomendasi Sistem}

Sistem informasi akuntansi yang diterapkan di LAZIS Nurul Falah belum terintegrasi antar Divisi. Sistem informasi yang belum terintegrasi dapat menimbulkan kesalahan dalam komunikasi dan penyebaran informasi, sehingga dapat berdampak pada proses penyusunan laporan keuangan. Setiap Divisi memiliki sistem masingmasing yang digunakan untuk mengelola data. Divisi Program dan Pentasyarufan menggunakan Google Sheet untuk proses input dan pengelolaan data Mustahik (Penerima ZIS). Begitupun dengan Divisi Fundraising yang menggunakan sistem sendiri yang bernama Sistem Informasi Donatur untuk pengelolaan data Muzakki (Orang yang membayar ZIS). Divisi Keuangan dalam menginput transaksi dan mengelola data keuangan LAZIS menggunakan aplikasi Retail yang didesain khusus untuk keuangan LAZIS Nurul Falah. Divisi Digital Marketing berperan dalam pengelolaan tabungamal.id dan memiliki database sendiri untuk menyimpan data Muzakki yang membayar zakat atau donasi melalui tabungamal.id. Sehingga setiap divisi memiliki database masing-masing. Untuk mengatasi permasalahan tersebut, direkomendasikan sistem baru dengan menggunakan sistem client-server. Rekomendasi sistem client-server dapat mengintegrasikan sistem dalam setiap Divisi di LAZIS NF. Sehingga berguna untuk peningkatan kinerja pengurus dalam mengelola dan mengakses data, serta lebih mudah dalam komunikasi dan berbagi informasi. Sistem client-server digambarkan sebagai berikut.

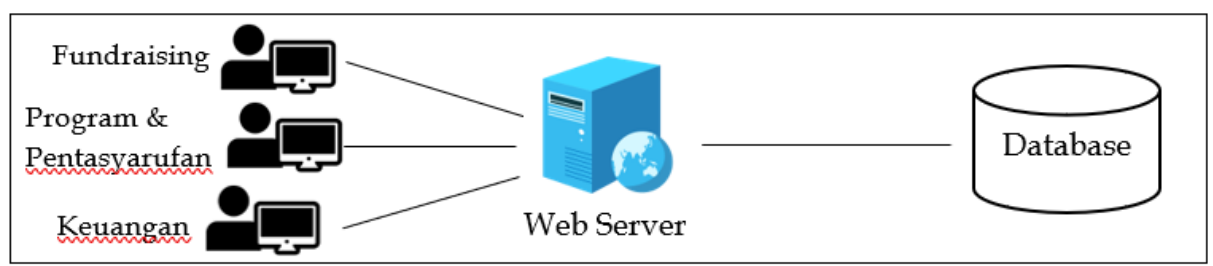

Sumber: data diolah Peneliti

Gambar 4.1. Sistem Client-Server.

\subsection{Desain Database}

Database merupakan kumpulan data yang saling terhubung untuk memusatkan data dan menyimpan suatu data dalam hardware. Database merupakan komponen penting dalam sistem komputerisasi karena memiliki peran dalam penyediaan informasi yang dibutuhkan. Pembuatan database menggunakan model ERD (Entity 
Relationship Diagram). Berikut usulan desain database untuk LAZIS Nurul Falah dalam bentuk relasi antar tabel.

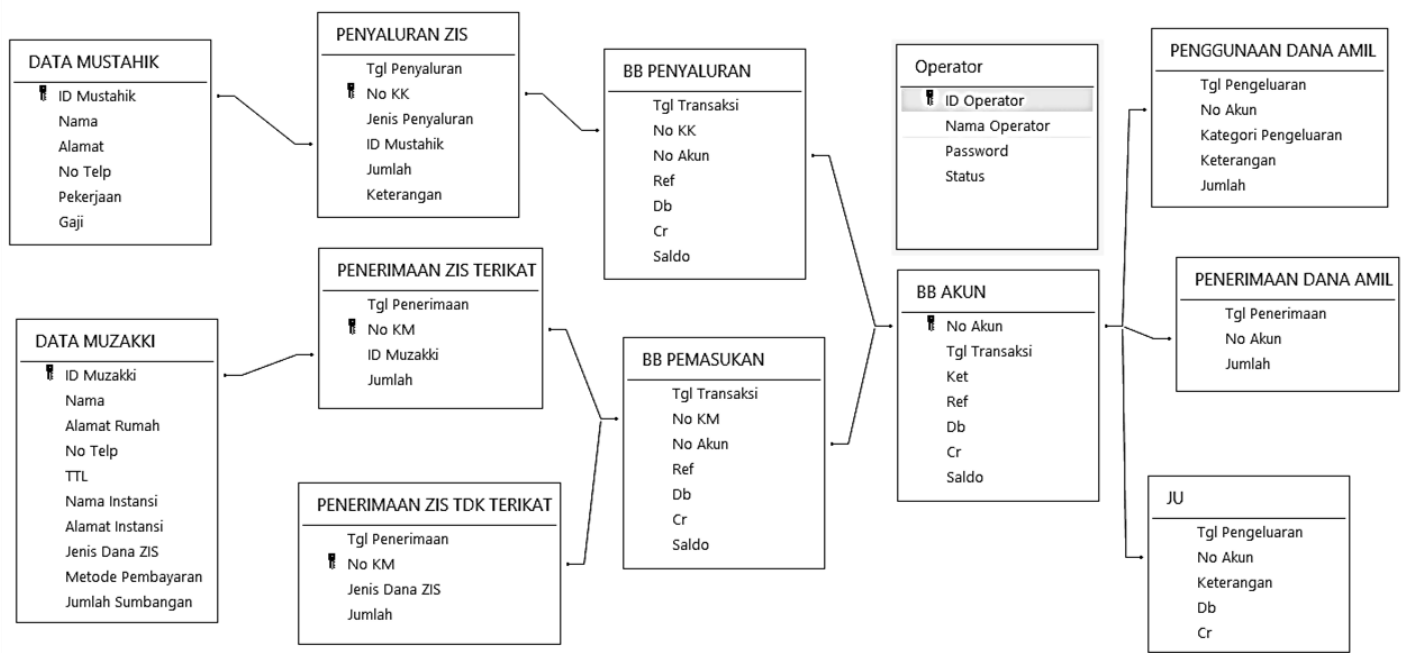

Sumber: data diolah Peneliti

Gambar 4.2. Relasi Antar Tabel

\subsection{Rancangan Sistem Informasi Akuntansi Penghimpunan dan Penyaluran Dana ZIS}

\subsubsection{Diagram Konteks}

Diagram konteks menggambarkan sistem secara luas. Diagram konteks adalah diagram yang memuat keseluruhan sistem informasi akuntansi yang menggambarkan interaksi antara sistem informasi akuntansi dengan komponen diluar sistem. Berikut usulan rancangan sistem informasi akuntansi untuk proses penghimpunan dan penyaluran dana ZIS

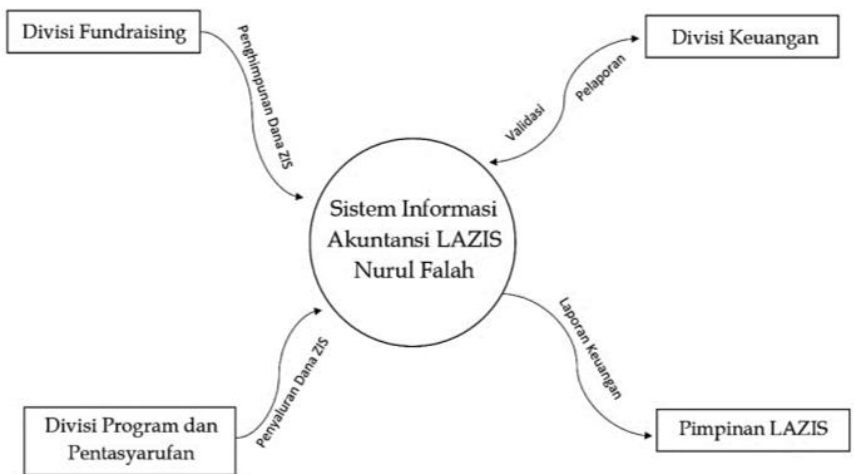

Gambar 4.3. Usulan Diagram Konteks

\subsubsection{Data Flow Diagram}

Data Flow Diagram (DFD) merupakan diagram alir yang menyajikan proses atau fungsi dengan melibatkan entitas eksternal. DFD berguna untuk mengetahui prosedur dari penghimpunan dana ZIS. Berikut usulan rancangan sistem informasi akuntansi untuk proses penghimpunan dana dan penyaluran ZIS. 


\subsubsection{Rancangan DFD Penghimpunan Dana ZIS DFD Level 0}

DFD Level 0 pada penghimpunan dana ZIS merupakan ringkasan keseluruhan aktivitas LAZIS NF dalam proses penghimpunan dana ZIS. Dimulai dari aktivitas registrasi Muzakki, pembayaran ZIS, hingga aktivitas pelaporan. DFD Level 0 digambarkan sebagai berikut

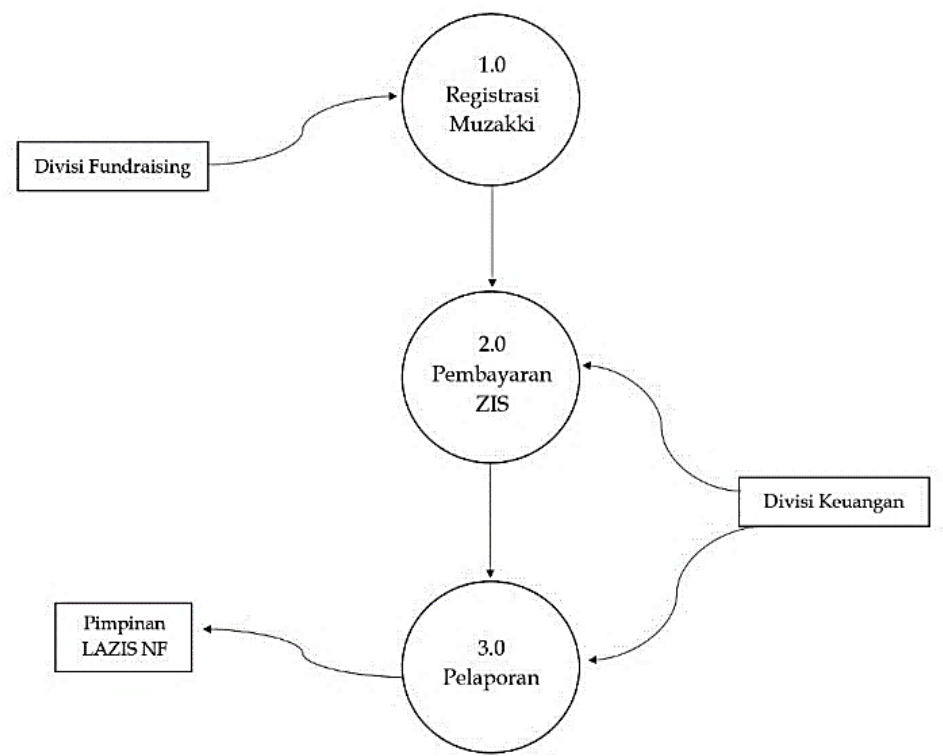

\section{Gambar 4.4. Usulan DFD Penghimpunan Dana ZIS Level 0}

\section{DFD Level 1}

DFD level 1 menggambarkan proses registrasi muzakki. Mulai dari pengisian formulir Muzakki sampai proses input data Muzakki. Berikut gambaran DFD level 1 yang diusulkan.

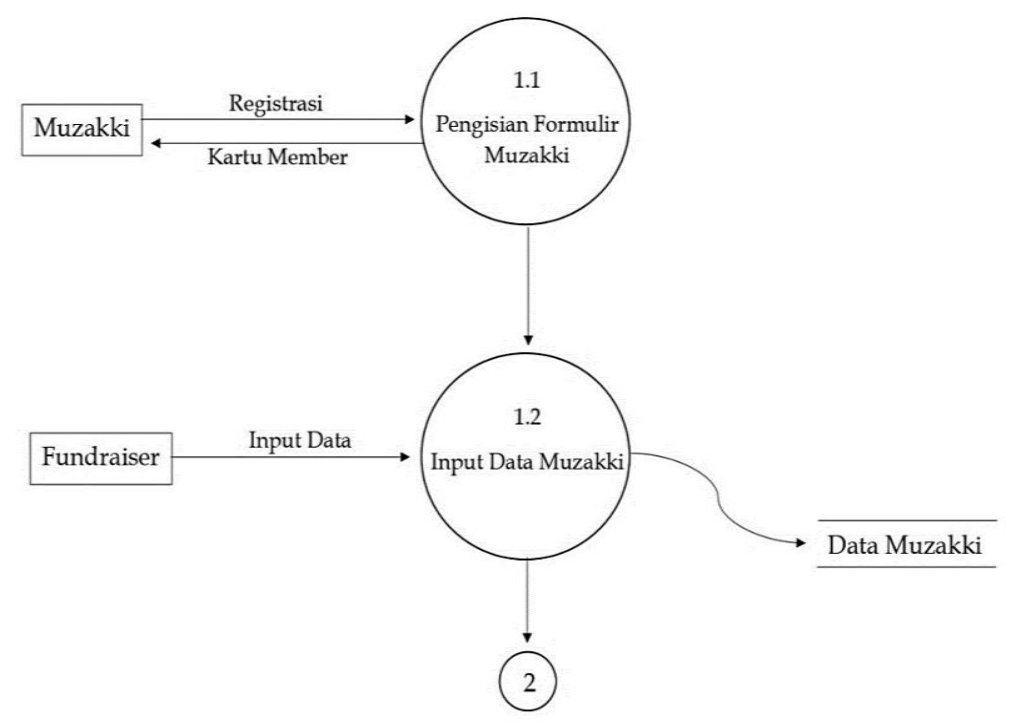

Gambar 4.5. Usulan DFD Penghimpunan Dana ZIS level 1

\section{DFD Level 2}


DFD level 2 menggambarkan proses pembayaran ZIS. Mulai dari penerimaan dana ZIS dan input transaksi pembayaran ZIS dalam sistem. DFD level 2 digambarkan sebagai berikut

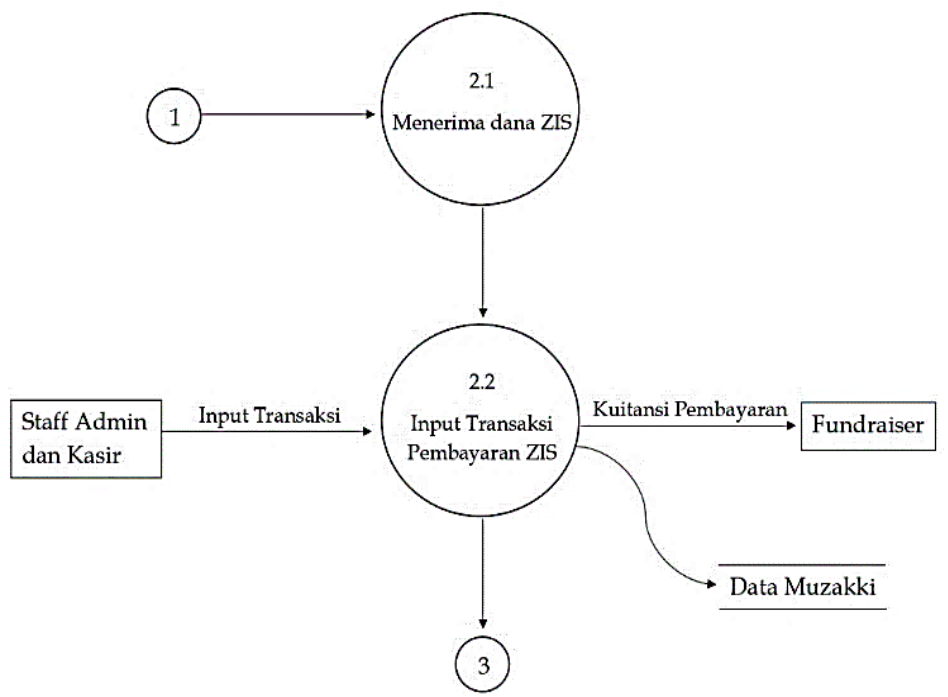

Gambar 4.6. Usulan DFD Penghimpunan Dana ZIS Level 2

\section{DFD Level 3}

DFD level 3 penghimpunan dana ZIS menggambarkan proses pelaporan keuangan. Setelah DFD level 1 dan DFD level 2 selesai dilakukan, maka DFD level 3 dimulai dari update buku besar, penyetoran ke bank, dan penyusunan laporan keuangan. Berikut gambaran DFD penghimpunan dana ZIS level 3 yang diusulkan

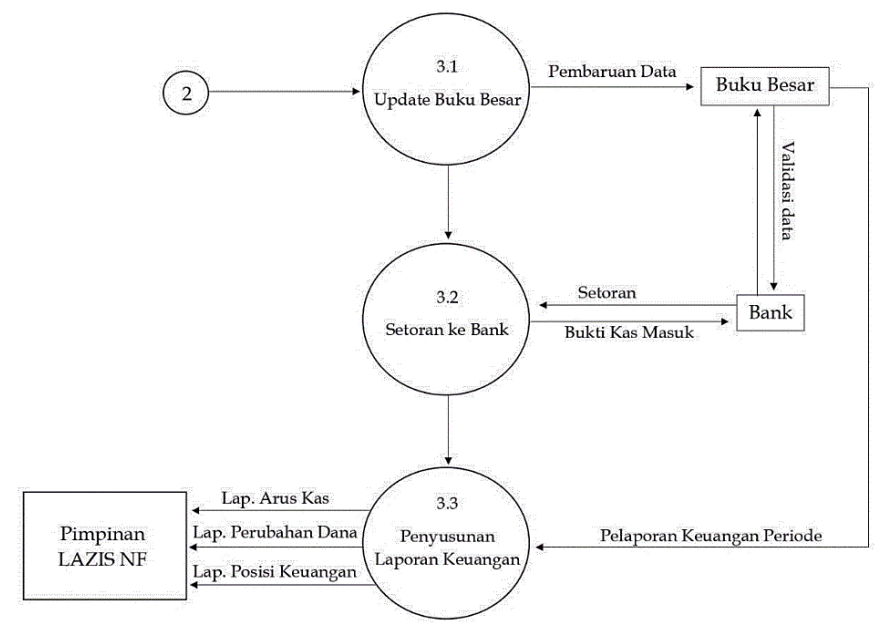

\section{Gambar 4.7. Usulan DFD Penghimpunan Dana ZIS Level 3}

\subsubsection{Rancangan DFD Penyaluran Dana ZIS}

\section{DFD Level 0}

DFD level 0 dalam penyaluran dana ZIS menggambarkan keseluruhan proses penyaluran dana ZIS. DFD level 0 dimulai dari penganggaran program, pencairan dana, dan pelaporan penyaluran ZIS. Berikut gambaran DFD level 0 yang diusulkan 


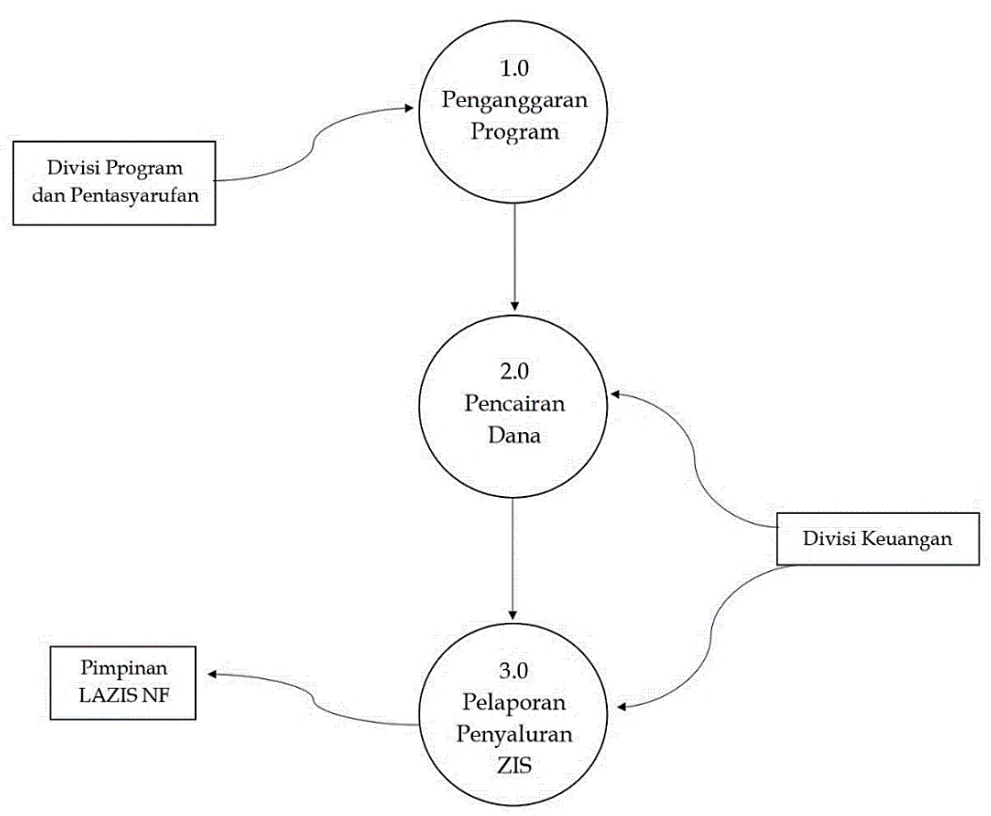

Gambar 4.8. Usulan DFD Penyaluran Dana ZIS Level 0

\section{DFD Level 1}

DFD level 1 penyaluran dana ZIS menggambarkan proses pengajuan anggaran kegiatan untuk penyaluran dana ZIS. DFD level 1 dimulai dari pengajuan dan persetujuan anggaran oleh Pimpinan LAZIS. Berikut gambaran DFD Level 1

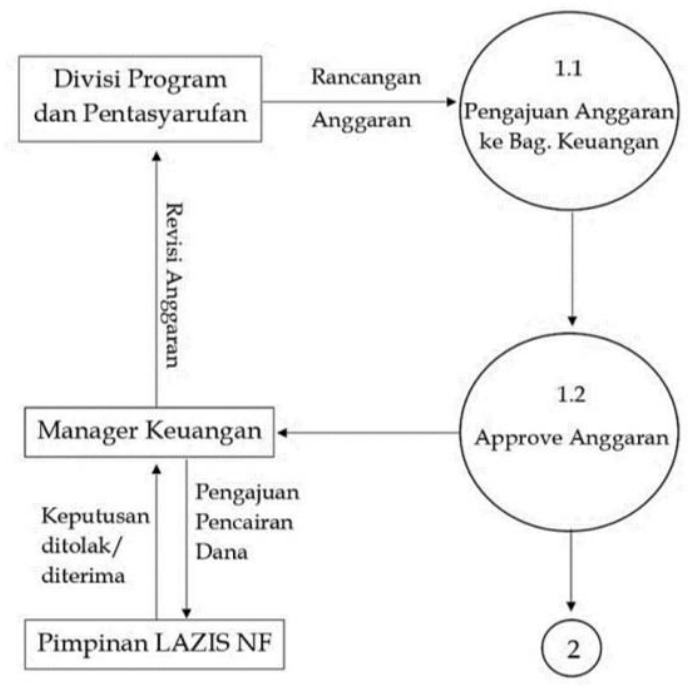

\section{Gambar 4.9. Usulan DFD Penyaluran Dana ZIS Level 1}

\section{DFD Level 2}

DFD level 2 penyaluran dana ZIS menggambarkan proses pencairan dana ZIS. DFD level 2 dimulai dari pencairan dana ZIS dengan cara menarik tunai dana di bank sampai proses penginputan transaksi pengeluaran dalam sistem. Berikut gambaran DFD level 2 yang diusulkan 


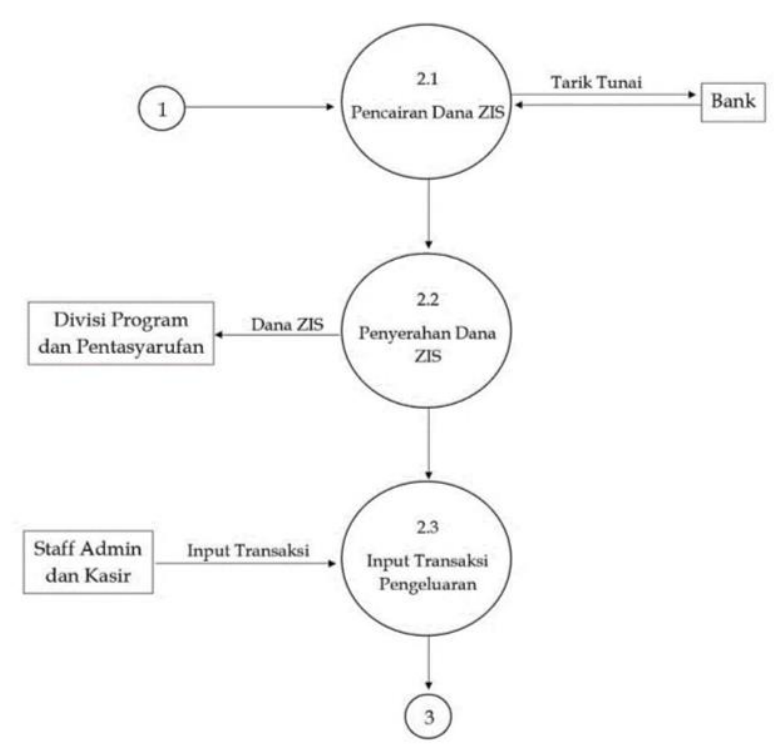

Gambar 4.10. Usulan DFD Penyaluran Dana ZIS Level 2

\section{DFD Level 3}

DFD level 3 penyaluran dana ZIS menggambarkan proses pelaporan keuangan dan pelaksanaan penyaluran ZIS. DFD level 3 dimulai dari update buku besar dan penyusunan laporan, baik laporan keuangan maupun laporan pelaksanaan kegiatan distribusi dana ZIS. Berikut gambaran DFD level 3 yang diusulkan

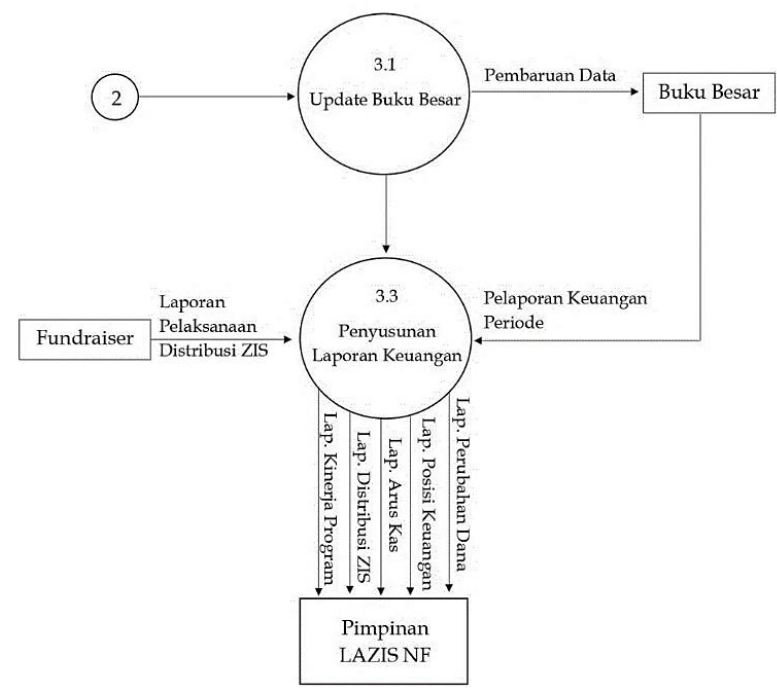

Gambar 4.11. Usulan DFD Penyaluran Dana ZIS level 3

\subsubsection{Flowchart}

Flowchart adalah diagram alir yang disajikan dengan simbol-simbol tertentu yang menggambar prosedur dari sistem informasi. Berikut usulan rancangan flowchart penghimpunan dana dan penyaluran dana ZIS.

\subsubsection{Flowchart Pembayaran Dana ZIS}

Flowchart yang diusulkan untuk pembayaran ZIS terbagi menjadi 3 sesuai dengan metode dan sifat dana ZIS yang dipilih oleh Muzakki. Pertama, flowchart 
pembayaran ZIS offline bersifat terikat yang digambarkan pada gambar 4.12. Kedua, flowchart pembayaran ZIS offline bersifat tidak terikat yang digambarkan pada gambar 4.13. Ketiga, flowchart pembayaran ZIS online yang digambarkan pada gambar 4.14.

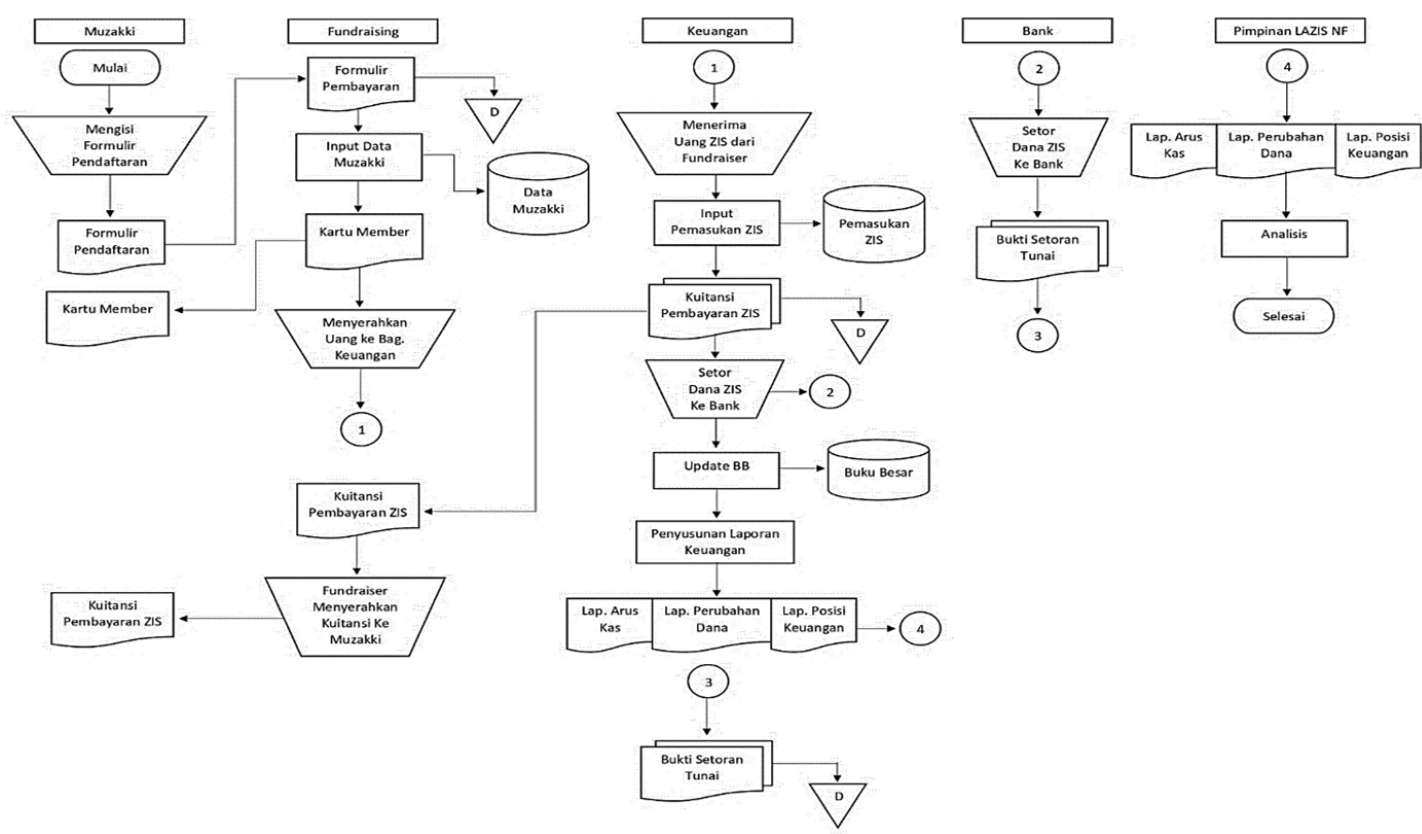

Gambar 4.12. Usulan Flowchart Pembayaran ZIS Offline Bersifat Terikat

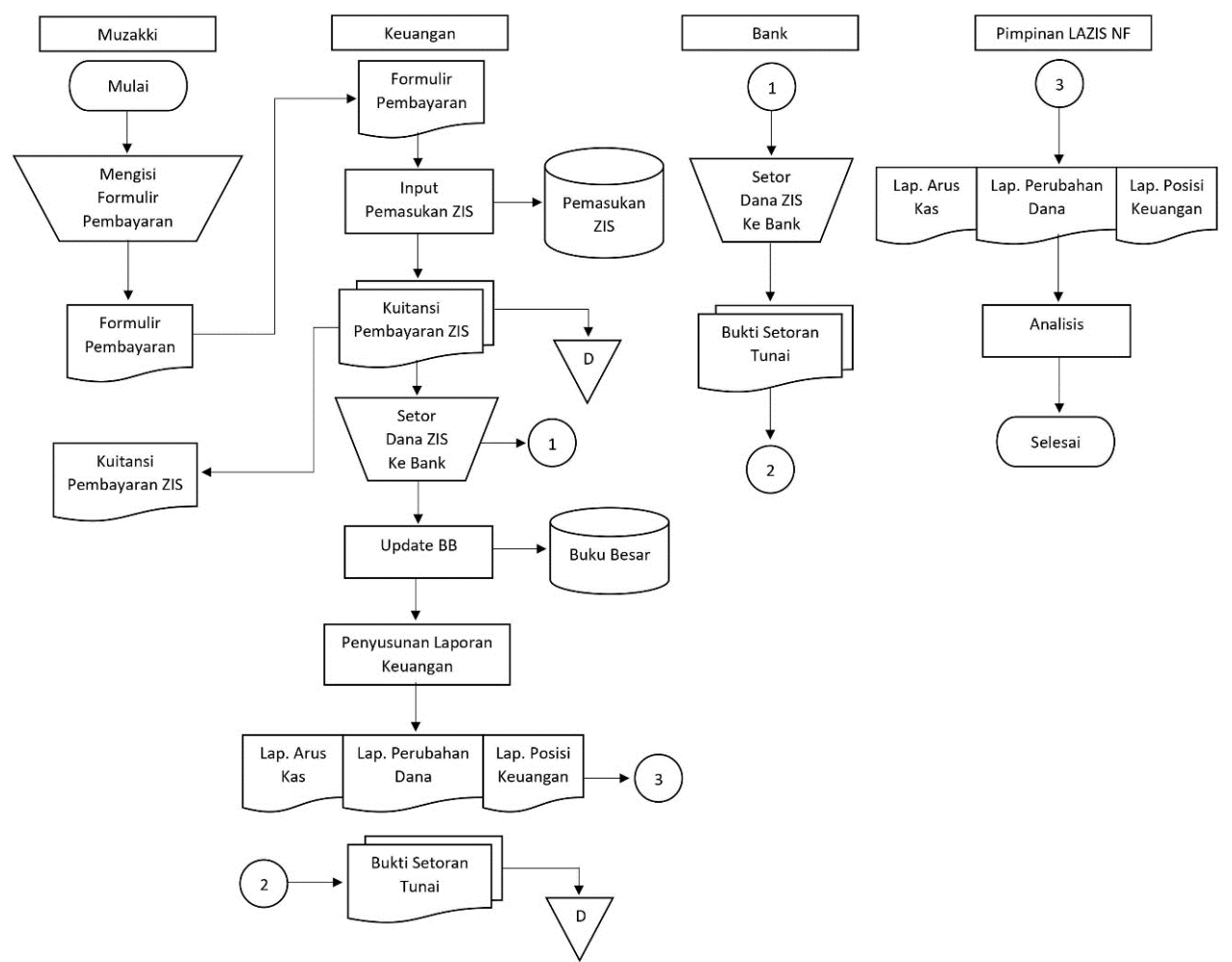

Gambar 4.13. Usulan Flowchart Pembayaran ZIS Offline Bersifat Tidak Terikat 


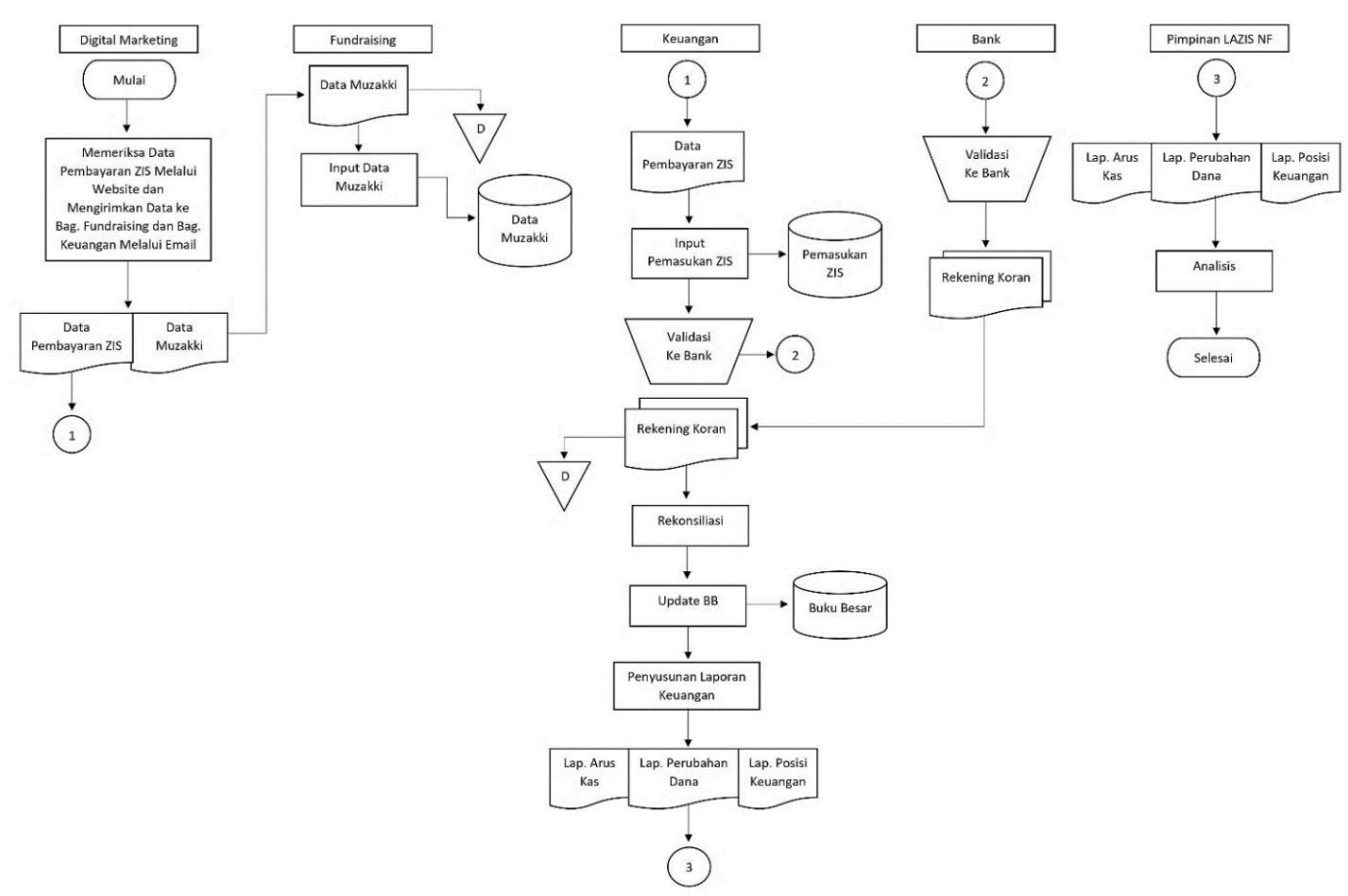

Gambar 4.14. Usulan Flowchart Pembayaran ZIS Online

\subsubsection{Flowchart Penyaluran Dana ZIS}

Flowchart yang diusulkan untuk penyaluran dana ZIS terbagi menjadi 2, yaitu penyaluran ZIS untuk program dan penyaluran ZIS untuk pentasyarufan langsung. Penyaluran ZIS untuk program digambarkan pada Gambar 4.15 dan penyaluran ZIS untuk pentasyarufan langsung digambarkan pada Gambar 4.16.

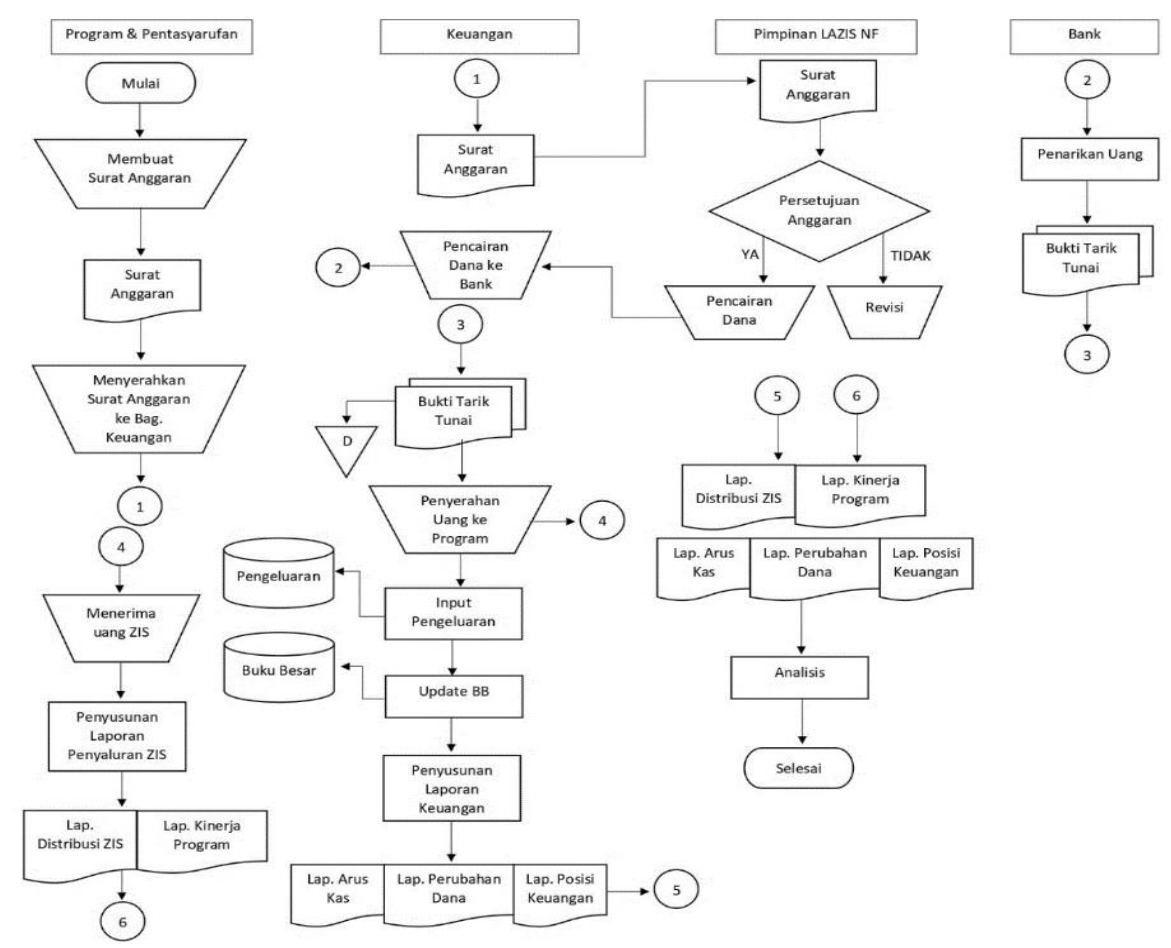

Gambar 4.15. Usulan Flowchart Penyaluran ZIS Untuk Program LAZIS 


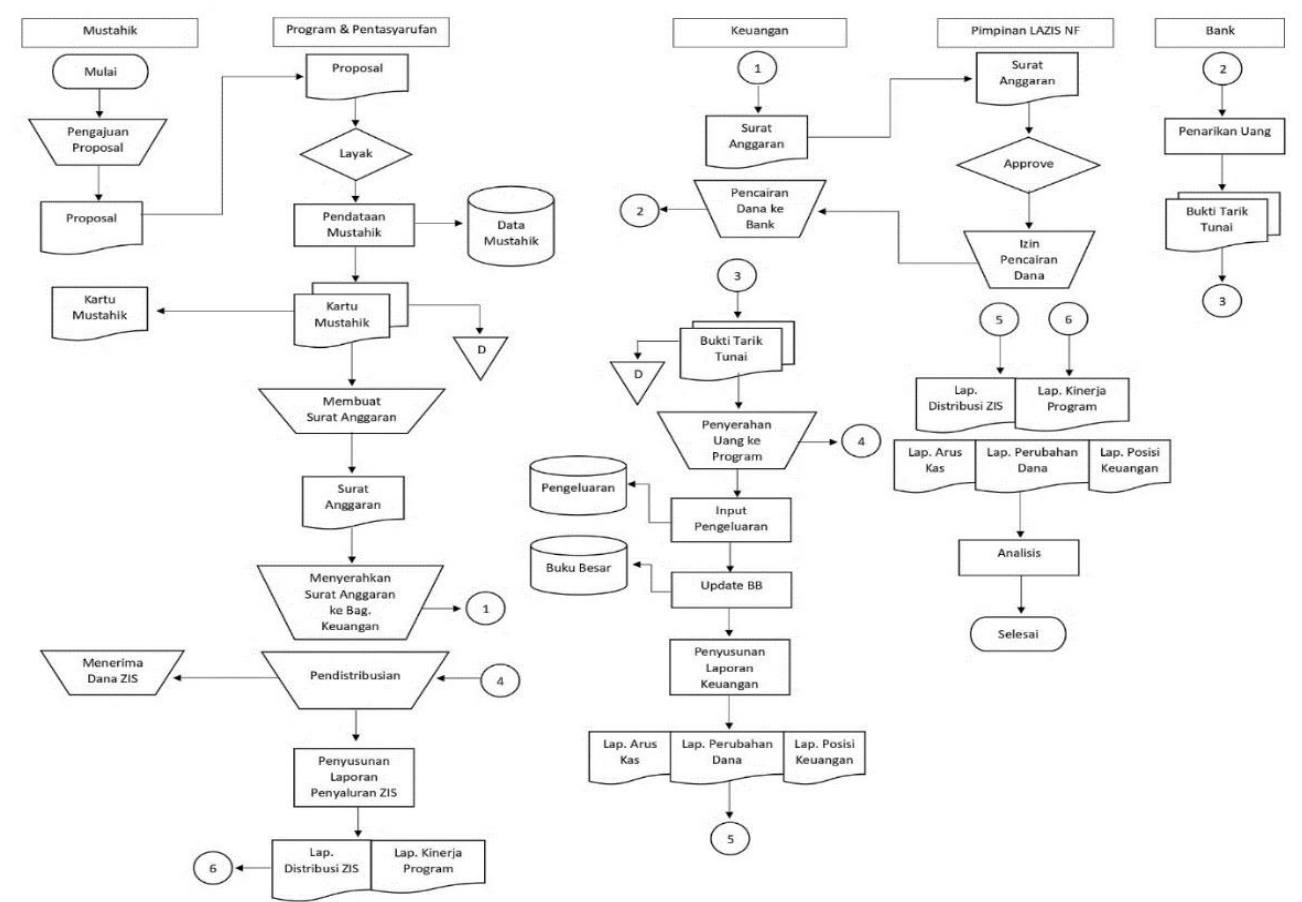

\section{Gambar 4.16. Usulan Flowchart Penyaluran ZIS Untuk Pentasyarufan Langsung}

\subsection{Rancangan Desain Kontrol}

Untuk meminimalisasi ancaman dan risiko pada sistem informasi akuntansi, perlu adanya pencegahan dengan diterapkannya sistem pengendalian internal. Menurut COSO (2012), terdapat 5 komponen pengendalian internal, yaitu lingkungan pengendalian, penilaian risiko, aktivitas pengendalian, informasi dan komunikasi, dan pemantauan. Perancangan sistem pengendalian internal yang diusulkan untuk LAZIS Nurul Falah berdasarkan model COSO sebagai berikut

1) Lingkungan Pengendalian

Dalam menciptakan sistem pengendalian yang baik diperlukan peran dari Pimpinan melalui kebijakan dan peraturan untuk menyadarkan seluruh pengurus mengenai pentingnya sistem pengendalian internal bagi organisasi (Olifia, Irsutami, dan Sinarti 2018). Kesadaran seluruh elemen pengurus mengenai pentingnya sistem pengendalian internal mendukung kelancaran terselenggaranya sistem pengendalian internal dalam organisasi. Perancangan pengendalian internal berdasarkan komponen lingkungan pengendalian sebagai berikut

a. Menyusun kebijakan etika kerja untuk menciptakan lingkungan kerja yang sehat,

b. Melakukan pemantauan terhadap pelaksanaan prosedur pengendalian terkait penghimpunan dan penyaluran ZIS secara berkala,

c. Menindaklanjuti semua temuan audit atas laporan keuangan,

d. Menyusun matrik kompetensi dan mengevaluasi kebutuhan kompetensi secara berkala untuk dasar pertimbangan dalam peningkatan kompetensi pengurus,

e. Melakukan recruitment pengurus untuk mengisi kekosongan bagian dalam struktur organisasi. Sehingga terdapat pemisahan tugas dan fungsi setiap pengurus dalam struktur organisasi. 


\section{2) Penilaian Risiko}

Penilaian risiko merupakan proses yang dinamis dan berulang untuk identifikasi dan menilai risiko yang memberikan dampak pada tujuan organisasi (Tuanakotta 2019). Penilaian risiko berguna untuk menentukan aktivitas pengendalian yang akan diterapkan dalam proses perancangan sistem pengendalian internal. Penilaian risiko berdasarkan sumber risiko dijelaskan dalam Tabel 4.1

Tabel 4.1. Sumber Risiko dan Risiko

\begin{tabular}{|l|l|l|}
\hline No & Sumber Risiko & \multicolumn{1}{c|}{ Risiko } \\
\hline 1. & $\begin{array}{l}\text { Sumber Daya } \\
\text { Manusia }\end{array}$ & $\begin{array}{l}\text { a. Risiko sabotase, pencurian, dan penyalahgunaan data } \\
\text { b. Risiko kesalahan dalam pencatatan transaksi } \\
\text { c. Risiko hilangnya data }\end{array}$ \\
\hline 2. & Alam & a. Risiko kerusakan hardware \\
\hline 3. & Kerusakan Sistem & $\begin{array}{l}\text { a. Risiko tidak berfungsinya sistem } \\
\text { b. Risiko hardware terserang virus }\end{array}$ \\
\hline
\end{tabular}

3) Aktivitas Pengendalian

Aktivitas pengendalian merupakan tindakan yang dilakukan manajemen untuk mencegah terjadinya risiko dan ancaman yang mungkin akan timbul. Aktivitas pengendalian berdasarkan risiko yang diusulkan untuk mencegah terjadinya risiko dapat dilihat pada Tabel 4.2

Tabel 4.2. Aktivitas Pengendalian

\begin{tabular}{|c|c|c|}
\hline No & Risiko & Aktivitas Pengendalian \\
\hline 1. & $\begin{array}{l}\text { Sabotase, pencurian, } \\
\text { dan penyalahgunaan } \\
\text { data }\end{array}$ & $\begin{array}{l}\text { - Pembatasan akses dengan melakukan login user } \\
\text { pada sistem } \\
\text { - Pemberian password pada file dan data } \\
\text { - Pemisahan tugas antara user dan pengurus lain }\end{array}$ \\
\hline 2. & Kesa & $\begin{array}{l}\text { - Pemberian fitur edit pada sistem dalam proses } \\
\text { penginputan } \\
\text { - Pemberian fitur verifikasi pada sistem dalam setiap } \\
\text { proses penghapusan data }\end{array}$ \\
\hline 3. & 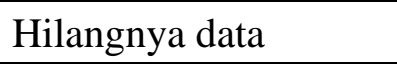 & ukan back up secara berkala \\
\hline 4. & Keru & $\begin{array}{l}\text { berikan perawatan terhadap hardware secara } \\
\text { la } \\
\text { ansurasikan hardware }\end{array}$ \\
\hline 5 . & Sistem tidc & $\begin{array}{l}\text { - Melakukan perawatan terhadap sistem secara } \\
\text { berkala }\end{array}$ \\
\hline 6. & $\begin{array}{l}\text { Hardware terserang } \\
\text { virus }\end{array}$ & $\begin{array}{l}\text { - Menginstal software antivirus } \\
\text { - Melakukan pembersihan data yang tidak } \\
\text { diperlukan secara berkala }\end{array}$ \\
\hline
\end{tabular}

4) Informasi dan Komunikasi

Informasi dan komunikasi memiliki peran penting baik untuk internal organisasi maupun eksternal organisasi. Rancangan pengendalian yang diusulkan untuk memudahkan organisasi dalam penyebaran informasi dan komunikasi sebagai berikut 
a.Pengadaan sistem informasi terintegrasi. Sistem informasi yang terintegrasi memudahkan organisasi dalam pertukaran informasi dan data antar divisi.

b.Memanfaatkan media komunikasi seperti e-mail dalam pengiriman file antar divisi atau pimpinan agar kerahasiaan file tetap terjaga.

c. Memanfaatkan media sosial dan website secara optimal dalam penyebaran informasi dan komunikasi dengan pihak eksternal.

\section{5) Pemantauan}

Kegiatan pemantauan dilakukan untuk memastikan bahwa organisasi berjalan sesuai dengan tujuan organisasi, visi, dan misi. Dalam LAZIS Nurul Falah terdapat Dewan Syariah yang bertugas untuk mengawasi kegiatan LAZIS NF. Rancangan pengendalian yang diusulkan adalah Pertama, Melakukan penilaian atau reviu terhadap efektivitas pelaksanaan pengendalian yang telah diterapkan dalam LAZIS secara berkala. Kemudian hasil evaluasi dikomunikasikan dengan manajemen untuk dilakukan peninjauan kembali kebijakan atau pengendalian yang telah diterapkan yang kemudian dilakukannya tindakan korektif. Kedua, Dewan Pengawas membentuk tim independen yang berkompeten untuk melakukan penilaian dan evaluasi terhadap efektifitas pengendalian internal yang berjalan. Tim independen harus independen dan objektif, artinya tidak memiliki kepentingan dan bisa membedakan antara kepentingan individu dan kelompok. Ketiga, Menyusun prosedur pengawasan agar terstruktur dan tepat sasaran.

\section{SIMPULAN, KETERBATASAN, DAN SARAN}

Dari hasil penelitian yang dilakukan pada LAZIS Nurul Falah dapat bahwa rancangan sistem informasi akuntansi yang direkomendasikan dapat mengintegrasikan sistem informasi akuntansi antar divisi pada LAZIS NF. Sehingga dapat mempercepat dan mempermudah dalam pengelolaan data dan keuangan, proses berbagi data, dapat meningkatkan kinerja pengurus, dan meningkatkan akuntabilitas dan transparansi pengelolaan dana ZIS. Keterbatasan penelitian yaitu informasi mengenai aplikasi pencatatan keuangan yang terbatas dan tidak memperoleh akses observasi mengenai cara kerja aplikasi pencatatan keuangan pada LAZIS Nurul Falah.

Setelah dilakukannya penelitian terhadap sistem informasi akuntansi pada LAZIS Nurul Falah, terdapat beberapa saran sebagai berikut

1. Besar harapan untuk mempertimbangkan rekomendasi sistem informasi akuntansi yang telah dirancang untuk diimplementasikan pada LAZIS NF. Sehingga dengan diimplementasikannya rancangan sistem informasi akuntansi tersebut sistem informasi akuntansi pada LAZIS NF terintegrasi.

2. Perlunya pelatihan terhadap pengurus dan pengguna sistem untuk meningkatkan kinerja pengurus.

3. Melakukan perawatan terhadap sistem untuk mengatasi kelemaham pada sistem dan untuk mengurangi risiko/ancaman terhadap sistem. 


\section{DAFTAR PUSTAKA}

Abral, Edi, Anwar, dan Syawal Harianto. 2016. "Perancangan Sistem Informasi Akuntansi Zakat Pada Lembaga Amil Zakat Di Kota Lhokseumawe.” Prosiding Seminar Nasional ASBIS 2016 Politeknik Negeri Banjarmasin, 81-99.

Asmarani, Marlia, dan Rohmawati Kusumaningtias. 2019. "Akuntabilitas Lembaga Amil Zakat Dalam Perspektif Maqashid Syariah (Studi Pada Yayasan Dana Sosial Al Falah Surabaya)." Jurnal Akuntansi AKUNESA 8 (1).

Badan Pusat Statistik Kota Surabaya. 2020. "Angka Dan Garis Kemiskinan Serta Jumlah Penduduk Miskin Kota Surabaya Tahun 2010-2019.” 2020.

Bashori, Ahmad Hasan. 2017. "Analisis Sistem Informasi Akuntansi Zakat, Infak, Sedekah (ZIS) Pada BAZ di Jawa Timur." Akuntansi: Jurnal Akuntansi Integratif 1 (1): 86-117.

Bodnar, George H, dan William S Hopwood. 2013. Accounting Information Systems Eleventh Edition.

Borhan, Omar Ahmad, dan Khan Nafees. 2018. "Effect of Accounting Information System on Financial Performance : A Studyof Real Estate Companies in Jordan." International Journal of Current Engineering and Scientific Research (IJCESR) 5 (1): 41-50.

Committee of Sponsoring Organizations of the Treadway Commission (COSO). 2012. Internal Control - Integrated Framework: Internal Control over External Financial Reporting, a Compendium of Approaches and Examples.

Dulkiah, Moh. 2017. "Peranan Lembaga Amil Zakat (Laz) Dalam Pemberdayaan Masyarakat Miskin Melalui Pengembangan Usaha Mikro Di Wilayah Jawa Barat." Jispo 7 (1): 30.

Ernawatiningsih, Ni Putu Lisa, dan Putu Kepramareni. 2019. "Effectiveness of Accounting Information Systems and the Affecting Factors." International Journal of Applied Business and International Management 4 (2): 33-40.

Firdaus, Dony Waluya. 2015. "Perancangan Sistem Informasi Akuntansi Zakat Dan Infaq / Sedekah Di Masjid Menggunakan PSAK No . 109.” Prosiding SAINTIKS FTIK UNIKOM 2 (109).

Ganyam, Amos Iorcher, dan John Ayoor Ivungu. 2019. "Effect of Accounting Information System on Financial Performance of Firms: A Review of Literature." Journal of Business and Management 21 (5): 39-49.

Habib, Anang Ariful. 2016. "The Principle Of Zakat, Infaq, And Shadaqah Accounting Based SFAS 109." Journal of Accounting and Business Education.

Hidayah, Nazilatul, dan Nawirah Nawirah. 2020. "Analisis Perlakuan Akuntansi Pembiayaan Qordhul Hasan Berdasarkan PSAK No. 59 Dan PSAK No. 101.” Jurnal Ekonomi Akuntansi Dan Manajemen 19 (2): 168.

Ikatan Akuntan Indonesia. 2008. Exposure Draft Pernyataan Standar Akuntansi Keuangan No. 109 Tentang Akuntansi Zakat, Infaq/Shadaqah. Jakarta: IAI.

Kieso, Donald E., Jerry J. Weygandt, dan Terry D. Warfield. 2011. Intermediate Accounting, Volume 1. IFRS. Vol. 1. Jakarta: Salemba Empat.

Komala, Adeh Ratna. 2017. "Cause and Effect of Accounting Information System: A Study in National Zakat Management Organization." Journal of Administrative and Business Studies 3 (2): 69-76.

Kristin P, Ari, dan Umi Khoirul Umah. 2011. "Penerapan Akuntansi Zakat Pada Lembaga Amil Zakat (Studi Pada LAZ DPU DT Cabang Semarang).” Jurnal 
Unimus 7 (109): 68-97.

Kusmanto, Arif. 2014. "Peran Lembaga Amil Zakat Nasional Dalam Penghimpunan Dana Zakat, Infaq, Dan Shodaqoh.” Pandecta: Research Law Journal 9 (2): 292. Lathifah, Nurul. 2019. "Perancangan Sistem Azis (Akuntansi Zakat, Infaq, Dan Sedekah) Pada Organisasi Pengelola Zakat Dalam Menghasilkan Laporan Keuangan." AKUNTANSI: Jurnal Akuntansi Integratif 05: 42-66.

Noerlina, Johan, dan Yuliana Yoswara. 2011. "Analysis and Design: Accounting Information System in Purchasing and Supplying." CommIT (Communication and Information Technology) Journal 5 (1): 18.

Nurhayati, Sri, dan Wasilah. 2013. Akuntansi Syariah Di Indonesia. 3rd ed. Jakarta: Salemba Empat.

Olifia, Jessica, Irsutami, dan Sinarti. 2018. "Perancangan Sistem Pengendalian Internal Berbasis COSO Pada Program Studi Di Politeknik Negeri Batam ( Studi Kasus Prodi Akuntansi Manajerial , Jurusan Manajemen Bisnis ).” Journal of Applied Accounting and Taxation 3 (2): 150-57.

Purwanti, Dewi. 2020. "Pengaruh Zakat, Infak, Dan Sedekah Terhadap Pertumbuhan Ekonomi Indonesia.” Jurnal Ilmiah Ekonomi Islam 6 (1): 101.

Puskas BAZNAS. 2021. Outlook Zakat 2021. Jakarta: Puskas BAZNAS.

Rahman, Taufikur. 2015. "Akuntansi Zakat, Infak Dan Sedekah (PSAK 109): Upaya Peningkatan Transparansi Dan Akuntabilitas Organisasi Pengelola Zakat (OPZ).” Muqtasid: Jurnal Ekonomi Dan Perbankan Syariah 6 (1): 141.

Robimadin, Cahya Nugeraha, dan Hendry Cahyono. 2020. "Kebermanfaatan Zakat Produktif Untuk Peningkatan Kesejahteraan Mustahiq Lembaga Manajemen Infaq Surabaya." Jurnal Ekonomika Dan Bisnis Islam 3 (2): 128-38.

Romney, Marshall B., dan Paul J. Steinbart. 2017. Accounting Information Systems. 14th ed. Pearson.

Rosa, D., dan A. P. Purfini. 2019. “Analysis Effect Quality of Accounting Information Systems to Support Company Performance." IOP Conference Series: Materials Science and Engineering 662 (3).

Soudani, Siamak Nejadhosseini. 2012. "The Usefulness of an Accounting Information System for Effective Organizational Performance." International Journal of Economics and Finance 4 (5): 136-45.

Susanto, Azhar. 2017. Sistem Informasi Akuntansi Pemahaman Konsep Secara Terpadu. 1st ed. Bandung: Lingga Jaya.

Tuanakotta, Theodorus M. 2019. Audit Internal Berbasis Risiko. Jakarta: Salemba Empat.

Vincent. 2020. "Dampak COVID-19, Angka Kemiskinan Indonesia Melonjak 26,4 Juta." Tirto.Id, July 15, 2020.

Wantoro, Agus. 2019. "Sistem Informasi Berbasis Web Untuk Pengelolaan Penerima Dana Zakat, Infaq Dan Sedekah.” Jurnal Tekno Kompak 13 (2): 31.

Yusuf, A. Muri. 2017. Metode Penelitian Kuantitatif, Kualitatif, Dan Penelitian Gabungan. 1st ed. Jakarta: Kencana. 